\title{
Responsible Parenthood: Reproduction and Religion in Post-War Britain
}

\section{Patrick T. Merricks}

"Man's development is influenced, not only by inborn qualities and dispositions and by environment, but also by a spiritual factor lying beyond both - namely, the grace of God." 1 Thus wrote Reverend Derrick Sherwin Bailey (1910-1984) in The Eugenics Review in 1959. In the 1950s and 1960s, British churchmen and eugenicists shared two major interests: the growing population and emerging fertility treatments. Increasing availability of birth control alongside astounding advances in human genetics have given us unparalleled control over the genetic constitution of future generations. As world population increased exponentially, post-war theologians and eugenicists recognised its significance. In engaging with these debates, this article explores a subject of increasing interest and importance to present and future society. The introduction outlines issues of agreement and contention between eugenicists and churchmen on 'responsible parenthood'; the first section details debates on contraception surrounding the 1958 Lambeth Conference and the passing of new government legislation on birth control and abortion a decade later; the second section explores contrasting opinions on artificial insemination and its use to improve society; the conclusion draws parallels between these opinions and how parenthood is discussed today. This article explores the very blueprints for current debates on over-population, in vitro fertilisation (IVF), pre-natal genetic diagnosis (PGD), prenatal screening, the human genome, and epigenetic inheritance. If eugenic and religious opinions were influential in shaping the understanding of reproductive technologies and habits in mid-century Britain, implementing new scientific techniques to improve the human species should heighten our inherent sense of moral responsibility.

\section{Introduction}

After the Second World War, the Anglican Church carefully monitored the world's growing population. Their concerns were articulated in publications like Richard Fagley's The Population Explosion and Christian Responsibility. 2 In 1960, the Professor of Christian ethics, Victor Obenhaus (1904-1994) bemoaned that "Intercontinental ballistic missiles (ICBM), [the] reunification of Germany, nuclear fallout, and the stored surpluses of agriculture and industry [...] have obscured the view of what may in the long run transcend all these other issues, namely the population explosion." 3 The heightening tensions of the Cold War distracted many from the long-term problem of global population growth - Anglicans were not only concerned with mankind's spiritual destiny, but its future as a species.

At the 1958 Lambeth Conference, the Anglican Church expressed its desire to play down the traditional Christian role of reproduction as the sole purpose of marriage. Instead, a loving marriage was one that made responsible use of contraception - a moral choice that benefitted the family and the community. The

\footnotetext{
1 Derrick Bailey, 'The Lambeth Conference and the Family', The Eugenics Review 50, 4 (January 1959), 245.

2 Richard Fagley, The Population Explosion and Christian Responsibility (New York: Oxford University Press, 1960).

3 Victor Obenhaus, 'Review: The Population Explosion and Christian Responsibility', The Journal of Religion 40, 4 (October 1960), 314.
} 
Anglican Church had gone from rejecting birth control at the 1920 Lambeth Conference, a reluctant acceptance for married couples in 1930, to presenting it in 1958 as the key to a happy marriage and healthy society. In a passage that highlights the overlaps between eugenic and religious views, the Archbishop of Canterbury, Geoffrey Fisher (1887-1972)was quoted in a newspaper report at the time thus: "Responsible parenthood, built on obedience to all the duties of marriage, requires a wise stewardship of the resources and abilities of the varying population needs and problems of society and the claims of future generations." 4 These concerns were shared by politicians and culminated in the government's passing of the 1967 National Health (Family Planning) and Abortion Acts. To the delight of eugenicists and churchmen, the former "made contraception readily available through the NHS by enabling local health authorities to provide advice to a much wider population." ${ }_{5}$ The latter was the beginning of the end for dangerous and illegal 'backstreet' abortions in the UK and, as a last resort, a means to safely avoid unwanted children being born into an inflated population. The contraceptive pill (readily available after the Family Planning Act) became both a symbol of and physical means to achieve female independence and emancipation from the 'traditional' role of wife and mother. This, in turn, influenced the rise of feminism in the 1970 s and 1980s.

To eugenicists, the spread of birth control among the highly fertile, and usually poorer sections of society or 'bad stocks'/problem families, 6 was one of the last tools available for controlling the biological 'quality' of the population at a time when eugenics was heavily discredited. National eugenic societies had influenced public policy and the nature of everyday life in the Americas, Europe and Asia. The involvement of German racial hygiene with Nazism was catastrophic for eugenic movements around the world. In Britain, the movement failed to regain the following it held before the war. The Eugenics Review ceased publishing in 1968 and eventually the Eugenics Society became the Galton Institute in 1989, which it remains today. Tellingly, one of the most outspoken eugenicists after the Second World War was a prominent churchman: Bishop E.W. Barnes of Birmingham (18741953). Until his death in 1953, Barnes warned of the dangers of 'racial intermixture' and pushed for the implementation of sterilisation and infant euthanasia for mental defectives into the new welfare state. Barnes was, however, an anomaly within the Eugenics Society and the Anglican Church, with few in either institution agreeing with his scientific racism or negative eugenics. Even so, recent scholarship on Barnes has revealed how polarised Britain was on the issue of eugenics after World War II, with many surprisingly in favour of preventing the 'inhuman' from reproducing.7

In the 1950s and 1960s, the Eugenics Society believed the philosophy of responsible parenthood could finally address its chief concern throughout the

\footnotetext{
4 Geoffrey Fisher quoted in 'Family Planning Guidance by the Bishops', The Times (26 August 1958), 3.

5 'National Health Service (Family Planning) Act 1967', Parliamentary Archives (1967) HL/PO/PU/1/1967/c39 [https://www.parliament.uk/about/living-heritage/transformingsociety/privatelives/relationships/collections $1 /$ parliament-and-the-1960s/national-health-service-family-planning-act/ accessed 12 September 2016].

6 See: Carlos Blacker, Problem Families: Five Inquiries (London: The Eugenics Society, 1952).

7 See: Patrick T. Merricks, 'Checking a "Scrub" Population: Bishop Barnes of Birmingham on Inner City Slums,' in Marius Turda ed. Revista de Anthropologie Urbana 5 (2015), 41-53 and idem 'God and the Gene': E.W. Barnes on Eugenics and Religion,' Politics, Religion and Ideology, 133 (September 2012), 253-74
} 
twentieth century: the differential birth-rate among the classes. If rarely by name, eugenicists still influenced British social policy with their continued involvement in associations like Planned Parenthood, originally founded by the Eugenics Society in 1930 as the National Birth Control Council.s The legacy of the British Eugenics movement survives today in the form of global charities like the International Planned Parenthood Association and Marie Stopes International. On a smaller scale, the Eugenics Society also helped found UK charities, like the Family Planning Association and Brook Advisory Centres. With the help of the internet and social media, such institutions now offer a range of contraceptive procedures and advice on sexual health to an ever increasing number of young, vulnerable adults.

The Anglican Church published numerous studies on emerging reproductive treatments, including 1962's Human Reproduction: A study of some emergent problems and questions in the light of the Christian Faith. The 45-page report dealt with contraception, artificial insemination, abortion and sterilisation. It was praised in The Eugenics Review for its "straightforwardness and clarity of purpose" and highlighted the "advance in Christian thought over the last few decades and the stage in its evolution so far reached." ${ }_{9}$ However, if there was agreement on contraception, this was not the case for artificial insemination (AI), now widely identified as in vitro fertilisation (IVF - the most successful technique to achieve artificial insemination). In the 1940s, the Archbishop of Canterbury organized an advisory group to establish the Anglican Church's position on the practice - here it was denounced as wholly unnatural and immoral. During the 1960s, as the technology developed many theologians began to argue that 'AlH' (using the 'H'usband's sperm) was acceptable for married couples who could not conceive 'naturally'. However, 'AID' (from a 'D'onor) was deplored by churchmen and perceived as only fit for an (either Aldous or Julian) Huxley-inspired dystopian future. In contrast, AID offered eugenicists the technology needed for national genetic improvement - the only problem was convincing a population all too aware of the Nazi experiment that eugenics could have any positive influence at all.

\section{Birth Control}

Popular attitudes to responsible parenthood have interested a range of scholars since the Second World War. Richard Hoggart's multi-edition book The Uses of Literacy (1957) provides a detailed critique of the massification of culture and habits of the working class. On religion, Hoggart observed that there were "few workingclass areas in which a substantial proportion of people still attend church or chapel," yet they remained "in some sense a part of the life of the neighbourhood." "10 Aside from attending Sunday school as children, many in Britain did not frequent Church every Sunday; yet, most still attended religious institutions at "the important moments of life or in times of personal crisis" like marriage ceremonies, baptisms and funerals. As Hoggart commented, "they are not simply taking out a saving policy; they still believe underneath, in certain ways." "11 Elsewhere, authors like Nigel Yates and Callum Brown agree that secularisation, the sexual revolution, and the short-lived

8 See: Margaret Pyke, 'Family planning: an assessment', The Eugenics Review 552 (July 1963), 71 9.

9 'Notes of the Quarter', The Eugenics Review (January 1963).

10 Richard Hoggart, The Uses of Literacy (Harmondsworth: Penguin, 1971, originally published 1957), 112.

11 lbid, 114. 
religious revival of the early-1950s, have been overstated in their immediate impact on the general population. 12 For example, the sexual revolution (the spread of contraceptive practices and rise of recreational sex) was felt mostly by the middleand upper-classes with the working class relatively untouched into the 1970s.

Clare Hanson has examined the extent to which eugenics became part of the national culture and remained so after the Second World War. Hanson's 2012 Eugenics, Literature, and Culture in Post-War Britain provides a striking insight into how, in the form of films and novels, the idea of eugenics as a way of life lingered in the minds of many during the post-war period. ${ }_{13}$ A decade or so after the conclusions of the Nuremburg Trials, some Anglican Churchmen continued to sympathise with eugenics in its 'purest' form: the furtherance of human evolution. Eugenics and religion were not necessarily incompatible. It was a theologian, Dean Inge (18601954), who was among the first to draw popular attention to eugenics in the 1910s and 1920s and after 1945 Bishop Barnes still had his supporters within the Anglican Church, albeit in greatly diminished numbers. The Eugenics Society arguably spent more time discussing birth control than any other eugenic measure; from 1909-1968 the phrase was used in The Eugenics Review twice as many times as 'sterilisation'. The former Society General Secretary and a leader of Planned Parenthood, Carlos Blacker (1895-1975) claimed in 1956 that responsible parenthood brought "the eugenics and birth control movements together; and unlike the standards based on class, it excites no prejudices." 14 Influenced by a lengthy memorandum submitted by the Eugenics Society at the tail end of the Second World War, 15 the 1949 Royal Commission on Population drew national attention to the importance of birth control concluding that: "The giving of advice on contraception to married persons who want it should be accepted as a duty of the National Health Service and the existing restrictions on the giving of such advice by public authority clinics should be removed." ${ }_{16}$ Despite this and the efforts of eugenicists and the birth control movement in establishing advice centres across the country, it was almost two decades before responsible parenthood was given its legal backing with the 1967 Family Planning Act.

The Anglican Church began to re-evaluate its official position on birth control with these issues in mind. Moreover, it is no coincidence that the Church's growing acceptance of birth control since 1930 coincided with the vast availability and comparative sophistication of contraception in mid-century Britain. Writing for the eugenic Population Investigation Committee on 'Birth Control and the Christian Churches', Flann Campbell (1919-1994) claimed that "a simple policy of silence or disapproval is not enough. Social realities must be faced, arguments met and answered, new formulae invented." 17 World population has grown exponentially since the nineteenth century, which for many Anglicans justified a deviation from the traditional Christian approach; birth control had fast become a moral necessity in

\footnotetext{
12 See: Nigel Yates, Love Now, Pay Later?: Sex and Religion in the Fifties and Sixties (London: Society for Promoting Christian Knowledge, 2010) and Callum G. Brown, Religion and Society in Twentieth-Century Britain (London: Routledge, 2014 first published 2006).

13 Clare Hanson, Eugenics Literature, and Culture in Post-War Britain (London: Routledge, 2012) 14 Carlos Blacker, 'Family Planning and Eugenic Movements,' The Eugenics Review 47, 4 (January 1956), 231.

15 Author Unknown, 'Royal Commission on Population: Memorandum submitted by the Eugenics Society', Eugenics Review 373 (October 1945), 92-104.

16 'A Royal Commission', The Times (17 April 1937), 3.

17 Flann Campbell, 'Birth Control and the Christian Churches', Population Studies 142 (November 1960), 143.
} 
civilised society. For the most part, this was not the case for Catholics, who were bound to Papal authority. In 1958, the Venerable Pope Pius XII (1876-1958) although equally interested in emergent reproductive technologies - declared that any form of contraception was a "grave violation of moral law" that interfered with the sacred act of procreation, something public authority had no right under any pretext to permit. ${ }_{18}$ Although most Church-goers in Britain were Protestant, a significant minority were Catholic and were guided by their local religious officials in line with the teachings of the Vatican. One observer commented that should the Anglican Church simply uphold its tentative acceptance of birth control established in 1930 at Lambeth, "the English bishops will have displayed an agility which a few Roman cardinals could almost bring themselves to envy." 19

Further reference to Hoggart reveals a negative contemporary view of the working class's breeding habits shared by many academics: "as in most aspects of domestic life, $[. .$.$] the wife is expected to be responsible for contraceptive practice." 20$ Having received limited guidance prior to marriage on family planning and the like, this was "a degree of sustained competence many wives are hardly capable of. She forgets just once or 'lets herself go', or a sheath is cheap and bursts, or the husband demands awkwardly after a night at the club. How often, therefore, it is assumed that any children after the first were 'not intended'." ${ }_{21}$ Within the middle-classes the rare occurrence of usually a third child, "who was 'not intended' is apt to arrive when the parents are about forty," some ten years after the first two. In contrast, unplanned working-class children were "likely to arrive only a year or two after the others. It is usually accepted 'philosophically'; after all 'what did yer get married for?'." 22 Until the 1958 Lambeth Conference, the Anglican Church too held that the sole purpose of marriage was to bring children into the world, regardless of the negative impact this had on the family and community. Blacker described the Church's official position up to this point: "The resolutions of the Lambeth Conference of 1908 and 1920 denounced contraception outright; that of 1930, carried by a three to one majority, was grudgingly permissive." 23 It is perhaps not surprising that the philosophy of responsible parenthood was yet to touch poor communities.

In early 1958 (in what was observed in eugenic circles as "a realistic effort to break new ground" ${ }_{24}$ ) a report titled 'The Family in Contemporary Society' was published at the behest of Archbishop Geoffrey Fisher of Canterbury by the Church of England's aptly named Moral Welfare Council. If eugenicists influenced the Anglican Church's opinions on population and family life to any degree, this is confirmed by the presence of Eugenics Society member and theologian, Derrick Bailey, as the Council's 'Study Secretary'. Bailey was an outspoken figure having authored Homosexuality and the Western Christian Tradition in 1955, which paved the way for the 1957 Wolfenden Report and the eventual decriminalisation of homosexuality. In publishing 'The Family in Contemporary Society', he intended to sway the Anglican Bishops meeting in the summer months at Lambeth Palace towards an official pronouncement in favour of the widespread use of contraception

\footnotetext{
18 'Pope Pius XII: One of His Last Talks to Doctors', The British Medical Journal, 2, 5102 (18 October 1958), 970.

19 Carlos Blacker in idem and Barbara Bosenquet, 'The Family in Contemporary Society', The

Eugenics Review 50, 2 (July 1958), 127

20 Hoggart, The Uses of Literacy, 45.

21 lbid.

22 Ibid, 46.

${ }_{23}$ Carlos Blacker in 'The Family in Contemporary Society', 127.

24 Barbara Bosenquet in Ibid, 126.
} 
for family limitation. The Anglican Church was becoming more progressive in some respects; yet, the Council also called women's education "the most disruptive force in all matters of family life". 25 This echoed arguments by British eugenicists during the Second World War, which had led to a lengthy and polarised debate on the role of women in society between male and female contributors to The Eugenics Review could a wife achieve fulfilment in the workplace and academic sphere, while also raising a family and satisfying the needs of her husband? Both the Anglican Church and the Eugenics Society wished to preserve traditional gender roles, a key reason they could unite under the philosophy of responsible parenthood.

One contributor to the abovementioned debate was Barbara Bosenquet (1906-1987) who declared that despite its misgivings, the 1958 Report proved that "the Anglican Church is concerned with family and population problems on a realistic basis. Also, it narrows the gulf between reverent agnostics and believers." ${ }_{26} A$ shared focus on the family, between churchman and eugenicist, blurred the line between Christianity and humanism that appeared so pronounced to many observers of (and contributors to) mid-twentieth century post-modern thought. Agreeing with the sentiments of the Council, Bosanquet argued that: "The best family (from a Christian and not merely a humanist point of view) is not that in which there are most children but that in which children grow up in an atmosphere of confidence and affection, fed by the 'mutual endearment' of parents who engage in regular intercourse without thereby producing more children than they can manage to rear." 27

A consensus was clearly forming within the Anglican Church that certain aspects of 'traditional' Christianity did not make sense in modern society. The proceedings of the Council made national news. In what it called "the most striking part" The Manchester Guardian summarised the publication's key argument thus: "The classical Christian attitude [disapproval] was formulated at a time when natural checks like war and disease seemed to guarantee the world against over-population. The advance of medical science has transformed the moral problem." 28 Universal healthcare was a dream long realised in Britain after the 1948 creation of the National Health Service. That infant mortality rates were at an all-time low, owed equal thanks to improvements in public health, advances in medicine, understanding of diet, training of doctors, medical equipment etc, during the first half of the twentieth century and before. The Report argued that this profound moral concern and sense of urgency should be transferred to spreading the philosophy of responsible parenthood: "Family Planning' represents an extension of the responsible use of science into the realm of procreation, in the immediate interest of the family and the more remote but no less real interest of society." 29 Never in Britain had Christians and eugenicists agreed to such an extent. Rather than a forgotten dream of the bygone era of modernism???, outdated in an instant with the discovery of the Nazi concentration camps, the eugenic spirit was alive and well. Blacker did not hesitate to voice his approval for the Church's new position: "This passage, which might almost have been written by Galton, could well be used as a text by eugenists." ${ }_{30}$

\footnotetext{
25 Bosenquet in Ibid, 126.

26 Ibid.

27 Ibid.

28 'Church and Family' and 'The Family in Contemporary Society', The Manchester Guardian $\left(15^{\text {th }}\right.$

April 1958), 3-8.

29 Quoted in Ibid.

30 Blacker, Ibid, 129.
} 
The 1958 Lambeth Conference was important for national acceptance of birth control and abortion. In terms of the latter, the attendees pled for "compassionate understanding of the predicaments which have compelled families and governments in some parts of the world to regard abortion as a more merciful thing than starvation." ${ }_{31}$ Indeed, The Times reported that "the acute problems of population in parts of the world like India and the Far East had caused the ninth Lambeth Conference to deal with family planning." ${ }_{32}$ It was hoped that Britain could set an example for the rest of the world in responsible parenthood. Derrick Bailey called its conclusions "rightly critical of the tradition which for so long has taught that procreation is the role or the principle purpose of marriage." ${ }_{33}$ Resolutions 112-131 were dedicated to 'The Family in Contemporary Society' under the premise that "all problems of sex relations, the procreation of children, and the organisation of family life must be related, consciously and directly, to the creative, redemptive, and sanctifying power of God." 34

The nineteenth century ideal that society could gradually progress towards higher states of enlightenment had been eroded by a range of factors, not least modernisation, the mass movement of populations, war, economic collapse, and extreme ideologies. All in one way or another seemed to threaten the traditional Christian idea of a healthy family. The Anglican Church also bemoaned other aspects of modern life, including the corrupting influences of journalism, radio and television - "those systems of migratory labour that break up family life" - and worse still drugs and alcohol or rather, the "widespread and growing reliance on undesirable and artificial means of responding to the restlessness of our present age." The weakening of family life and social cohesion from the "sheer silliness and the low standard of social morality" threatened to permanently retard spiritual wellbeing in the Christian world. 35 If the views of the Church reflected those of the established elite, it was in wishing to maintain public order by protecting the 'traditional' family structure. This was confirmed with the 1964 Drugs (Prevention of Misuse) and 1965 Dangerous Drugs Acts, which in accordance with various decrees from the United Nations criminalised the cultivation and use of cannabis and amphetamines, among others, in Britain. 36

The 1958 Lambeth Conference also discussed family planning at length. Resolution 115 expressed that "the responsibility for deciding upon the number and frequency of children has been laid by God upon the consciences of parents everywhere; that this planning, in such ways as are mutually acceptable to husband and wife in Christian conscience, is a right and important factor in Christian family life." 37 No longer was "sexual love an end in itself nor a means to self-gratification" but rather "self-discipline and restraint [...] essential conditions of the freedom of marriage and family planning." 38 Bailey expressed his delight to the Eugenics Society that "the unity and harmony between the different functions or aspects of sexuality

\footnotetext{
31 Bailey, 'The Lambeth Conference and the Family', 245.

32 'Family Planning Guidance by the Bishops', The Times (26 August 1958), 3.

33 Derrick Bailey, 'The Lambeth Conference and the Family' The Eugenics Review 504 (January 1959), 240.

34 'Resolution 112' in The Lambeth Conference: Resolution Archive from 1958, 28

[http://www.anglicancommunion.org/media/127740/1958.pdf, accessed 27 September 2016].

35 'Resolution 127' in Ibid, 32.

36 'Drugs (Prevention of Misuse) Act 1964', Parliamentary Archives 64 [HL/PO/PU/1/1964/c36

accessed 4/10/2016].

37 'Resolution 115' in Ibid, 29.

38 'Resolution 113' in Ibid.
} 
can be broken more easily than ever." While the Old Testament encouraged people be fruitful and multiply, it was written at a time when "under-population rather than over-population was the dominant reality." 39 In accepting the social value of responsible parenthood, the Church now committed itself to adapting its teachings to support the family in what the Archbishop called "an age of rapid social change." 40 In a total inversion of 'traditional' religious responses to birth control, the 1958 Lambeth Conference recognised churchmen as the leaders in spreading knowledge on responsible parenthood, welcoming "the increasing care given by the clergy to preparation for marriage both in instructing youth, through confirmation classes and other means." 41 This was not just the responsibility of the clergy but of lay people too: "The Conference welcomes the growth of marriage guidance councils, [...] given as a Christian vocation by well-trained Christian husbands and wives, is a volunteer service of great value, makes an important contribution to the community, and deserves government support." 42

Bailey also discussed the eugenic significance of the Conference at a Members Meeting for the Eugenics Society in November 1958. The Bishops spent considerable time discussing eugenic sterilisation, some even sympathising with the practice, before eventually dismissing it. While "its value as a family planning device suited to poor and illiterate peoples was appreciated, though not approved," it was incompatible with the Christian idea of a free person. ${ }_{43}$ Nevertheless, with churchmen taking an active interest in limiting the number of children produced within marriage, Bailey concluded that eugenicists should be "profoundly grateful to the bishops for their labour on 'The Family in Contemporary Society', and we may confidently expect to see it bear fruit before their lordships are again invited to confer at Lambeth in ten years' time." 44

Bailey's prophecy proved accurate as the push for government support was successful with the passing of the 1967 Family Planning and Abortion Acts. In the intervening years, the Eugenics Society also went to great efforts to promote responsible parenthood. A key figure here was Helen Brook (1907-1997). In 1958, thanks to her admirable volunteer work for Carlos Blacker's Planned Parenthood Association (she also went on to serve as its Chairmen and then President in the 1960s and 1970s), the Eugenics Society entrusted Brook to take over the Marie Stopes' birth control clinic after Stopes' death. According to Lesley Hall, unlike the PPA and marriage guidance offered by the Anglican Church, Stopes' clinic did not confine itself to married or soon to be married women alone; it focussed more on poor single women seeking advice on contraception at a time when there were no official bodies to turn to. ${ }_{45}$ She established the Brook Advisory Centres in 1964 which offered strictly confidential council on reproduction to all young single people - men and women - under 25. By the end of the 1960s, the Centres had expanded nationwide offering advice to over ten thousand unmarried people, with most aged

\footnotetext{
39 Fagley, The Population Explosion and Christian Responsibility, 15.

40 Geoffrey Fisher quoted in 'Notes of the Quarter', The Eugenics Review (October 1958), 156.

41 'Resolution 114' in Ibid.

42 'Resolution 117' in Ibid.

43 Bailey, 'The Lambeth Conference and the Family', 244.

44 lbid.

45 Lesley Hall, 'Half a century of helpful people with helpful answers', From the Collections (12 July 2014), Wellcome Library [http://blog.wellcomelibrary.org/2014/07/half-a-century-of-helpful-peoplewith-helpful-answers/\# accessed 4/10/2016]. See also: Ann Furedi, 'Obituary: Helen Brook', Independent (8 October 1997) [http://www.independent.co.uk/news/obituaries/obituary-helen-brook1234802.html accessed 4/10/2016] and.
} 
between 19 and 25 and one-sixth under 19.46 Half a century later, alongside the website 'brook.org.uk' the charity 'Brook' helps 250,000 young people across the country. ${ }_{47}$ Considering the Centres' humanist (and Christian) ideals that provide aid to such people in desperate situations, it is curious (and perhaps somewhat jarring) that they were originally created by the Eugenics Society to reduce swelling numbers in the working class.

The 1967 Family Planning Act confirmed that irresponsible parenthood was a national issue. 48 To combat this, the Act made contraception readily available through the NHS by "enabling local health authorities to provide advice to a much wider population. Previously, these services were limited to women whose health was put at risk by pregnancy." ${ }_{49}$ The MP Edwin Brook had put it forward as a Private Members Bill, having identified "a social problem whereby low income groups were at risk of economic struggle through having more children than they could afford." 50 The Act also protected the confidentiality of those seeking advice. For example, a 1971 issue of the British Medical Journal Supplement reveals a case in which a family doctor had received a letter from a Brook Advisory Centre to prescribe the contraceptive pill to a girl of 16. After informing the girl's parents, the doctor was examined and eventually cleared of misconduct for breaching confidentiality. Providing a glimpse into the mindset of the public, the mother expressed her relief thus: "Well, if it has to be, thank God she had enough sense to protect herself." 51

The same year as the Family Planning Act, the government also passed the 1967 Abortion Act. Despite its prior illegal status, abortion also had a prominent place in the national psyche. Alongside contraception it featured in films like Alfie (1966), starring Michael Caine and Shelley Winters, works of fiction like Penelope Mortimer's Daddy's Gone A-Hunting (1958) and non-fiction like Storm Jameson's Journey to the North (1969) and The Nameless: Abortion in Britain Today (1966); all of which discuss and document at length the social stigmas surrounding the practice and different means to end pregnancy outside of the law.52 The 1967 Abortion Act made the procedure acceptable, albeit only in a medical emergency. The strictness of the Act is evidenced by several cases brought to the General Medical Council's Disciplinary Committee. For example, a 'Dr. Mansoor Soomro' was charged with professional misconduct and imprisoned for aborting the child of a 16-year-old after:

\footnotetext{
46 Ibid.

47 By the time of her death in 1997 there were 18 branches in the UK funded by local health authorities and today advice is freely available on the website in the form of videos and FAQS. See: 'Brook, the young people's sexual health \& wellbeing charity', [https://www.brook.org.uk/ accessed 4/10/2016].

48 'National Health Service (Family Planning) Act 1967', Parliamentary Archives 39 (28 June 1967), HL/PO/PU/1/1967/c39.

49 'National Health Service (Family Planning) Act 1967' in Parliament and the 1960s

[https://www.parliament.uk/about/living-heritage/transformingsociety/private-

lives/relationships/collections 1/parliament-and-the-1960s/national-health-service-family-planning-act/ accessed 4/10/16].

$50 \mathrm{lbid}$

51 Author Unknown, 'Professional Secrecy', British Medical Journal Supplement (20 March 1971), 79. 52 See also: Barbara Brookes, Abortion in England, 1900-1967 (London: Croom Helm, 1988); and Lesley Hall, Literary Abortion [http://www.lesleyahall.net/abortion.htm accessed 26/10/2016]. Although this is an underdeveloped area of research, work is currently being conducted on 'Representations of Abortion in British Literature and Film from around 1918' at the University of Cambridge [http://www.english.cam.ac.uk/admissions/graduate/PhD_Info_Modern.htm accessed 26/10/16].
} 
"The pregnancy was confirmed but nothing was said about there being any danger or risk of injury to the girl if it was allowed to continue." 53

Although the 1967 Abortion Act legalised abortion in the case of medical emergencies, the 'pro-choice' abortions that we know today (at least in Britain) were not an option; life-threatening 'backstreet' abortions and home-brewed noxious concoctions provided the only solution to poor and desperate women. Instead, unwanted pregnancies continued to produce unwanted children. It was not until 1990 that these laws were relaxed and abortions became more freely available after the passing of the Human Fertilisation Act. Notably, one new stipulation that allowed for abortion after the 1990 Act was if "there is a substantial risk that if the child were born it would suffer from such physical or mental abnormalities as to be seriously handicapped." ${ }_{54}$ The 1990 amendments have allowed more people from poorer backgrounds to undergo abortion and in some cases, prevent children being born with what eugenicists may have termed 'mental deficiency'. While not the case in 1967, the Act has evolved to a state in which it could be used for eugenic purposes if popular opinion was swayed in favour of the eugenic cause (in this case responsible parenthood and ridding the world of hereditary disease). The government archive page concludes that the 1967 Family Planning and Abortion Acts meant that "women were able to take control of their own fertility for the first time." ${ }_{55}$ While the Acts are remembered as part of the women's liberation cause, the Family Planning Act was passed (at least partially) in the interests of controlling the population and its genetic progress and the Abortion Act, for only exceptional circumstances in which the procedure could save the mother's life.

\section{Artificial Insemination}

In post-war Britain, many began thinking seriously about the uncertain future of the human species. Certainly, the possibility of nuclear war increased throughout the 1950s, and almost became a reality due to events in Berlin and Cuba at beginning of the 1960s. The nuclear arms race was a threat to humanity's evolution, whether through the potential degenerative effects of radiation on human genes or more broadly, the destruction of the planet. Many turned to artificial insemination and sperm banks to protect the species. Carlos Blacker claimed in 1958 that "if the threat of all-out nuclear war is sufficient to require the continuous maintenance in the air of American planes loaded with $\mathrm{H}$ bombs, it should also call for the construction of underground seminal banks, protected from radiations." ${ }_{56}$

Artificial insemination was nothing new in mid-century Britain. The physician John Hunter (1728-1793) performed the first documented application in eighteenth century London. The technique was developed slowly and experiments took place in the nineteenth and early twentieth centuries conducted by figures like J. Marion Simms in the United States, Walter Heape at Cambridge and V.K. Milovanov in Russia. New effective methods to preserve sperm and a greater understanding of the menstrual cycle meant that the technique could also be applied to livestock with

\footnotetext{
53 Author Unknown, 'Imprisonment for Abortion', British Medical Journal Supplement (20 March 1971), 77-8.

54 'Medical termination of pregnancy,' Abortion Act 1967 [1990 amendments] [http://www.legislation.gov.uk/ukpga/1967/87/section/1 accessed 4/10/2016]. 55 lbid. 56 Carlos Blacker, 'Artificial Insemination: The Society's Position', The Eugenics Review 50, 1 (April 1958), 51.
} 
great success, beginning in the inter-war United States. 57 By 1960, it was used for all forms of UK livestock apart from chicken.58 Eugenicists agreed that its use in agriculture had "much shortened the mental step involved in recognizing its bearings on human infertility and even, potentially, on human improvement." ${ }_{59}$ The first successful human pregnancy using frozen sperm also took place in the US in 1953. However, this technique was highly controversial at the time and described as "contrary to public policy and good morals." ${ }_{60}$ Ombelet and Robays have suggested "it is not surprising that nearly a decade passed before the first successful birth from frozen sperm was announced in public: a major breakthrough in history." ${ }_{61}$ Artificial insemination brought with it a host of moral issues. It was generally agreed, along with Derrick Bailey, that the procedure "allows generation to be abstracted completely from any kind of personal relation." 62 This had profound and surprising effects on the way the practice was eventually accepted in society. In 1958, divorce courts in Edinburgh and Chicago ruled in the wives' favour that AID was not adultery, as it did not involve sexual intercourse. 63 The Manchester Guardian suggested that now most objections were undermined by the law, it would give doctors more confidence in performing the procedure.64

British eugenicists took significant interest in artificial insemination and it featured in over 100 Eugenics Review articles. AID represented the most rational and efficient means of selective breeding. While negative eugenics - including contraception, abortion and sterilisation - dealt largely with the problems of the present, artificial insemination was focussed directly on the future. While Marie Stopes and J.B.S. Haldane had flirted with the idea in the early twentieth century, it first become a significant eugenic discourse in 1935 with Herbert Brewer.65 In his article 'Eutelegenesis', Brewer claimed it would "transform the problem of negative eugenics." Whereas "the elimination of [...] degeneracy by sterilizing" would be like "clearing a river of fish by catching the few which jump from the water," AID would ensure that the "existence of the whole inextricable tangle of latent defect" would be swept out "in a few generations, replacing it concurrently with hereditary material of the highest excellence." 66

Together with Julian Huxley (1887-1975) and Hermann J. Muller (1890-1967), Brewer was part of a circle of eugenic ideologues (which also included the likes of Haldane and George Bernard Shaw) who favoured the political left and saw artificial insemination as the future of human reproduction. As Huxley had put it: "Eugenics has sometimes been attacked as a mere rationalization of class prejudices. [...] [However,] the inherent diversity and inequality of man is a basic biological fact; and Eugenics is the expression of a wish to utilize that fact in the best interests of future

57 W. Ombelet and J. Van Robays, 'Artificial Insemination History: hurdles and milestones', Facts Views Vis Obgyn 72 (2015), 140.

58 'Control of Artificial Insemination', The Times 19 June 1960), 14.

59 Blacker, 'Artificial Insemination', 51.

60 Ombelet and Robays, 'Artificial Insemination', 140.

$61 \mathrm{lbid}, 141$.

62 Bailey, 'The Lambeth Conference and the Family', 241.

63 See: 'Insemination not Adultery', The Times (11 January 1958), 6; 'Legality of Artificial

Insemination: Chicago Judge's Ruling', The Times (14 December 1954), 8; 'Artificial Insemination not Adultery', The Manchester Guardian (11 January 1958), 5.

64 'Effect of lord Wheatley's ruling', The Manchester Guardian (13 Jan 1958), 5.

65 See: Martin Richards, 'Artificial Insemination and Eugenics: Celibate Motherhood, Eutelegenesis

and Germinal Choice,' Studies in History and Philosophy of Biological and Biomedical Sciences 39, 2 (June 2008), 211-221.

66 Brewer, 'Eutelegenesis,' 123. 
generations." 67 In 1937, Brewer expanded on this: "the aims of eutelegenesis are socialism, biological socialism [...] nothing less than socialization of the germ plasm, the establishment of the right of every individual that is born to the inheritance of the finest hereditary endowment that anywhere exists." 68 The proposal was met with much caution, with his overt references to socialism doing nothing to quell any opposition. Other concerns ranged from fears about public reaction to practical difficulties, such as "finding [an] acceptable method of obtaining semen."69

It would be long into the post-war period before these issues were overcome. Even then, in the first couple of decades the service was used exclusively by married couples. As Martin Richards summarised: "A couple's desire to have their 'own' children has always seemed stronger than any eugenic aspirations." 70 Even so, in 1950 Blacker described how AID had been successfully used for eugenic purposes, "in cases when the male partner is at fault and also when, because of hereditary infirmities in himself or his family, he does not want children of his own. The Society holds that while caution is needed in espousing this revolutionary biological innovation, the practice of which should not outrun prevailing laws and sentiments, it should not be legally prohibited." 71 Later, Bailey also referenced isolated cases where couples had used AID to avoid passing on the husband's epilepsy.

After the Nazi experiments of selective breeding, no one articulated more caution towards artificial insemination than the Anglican Church. The sexual relationship between a man and wife was sacred; yet, artificial insemination conjured images of Aldous Huxley's Brave New World, in which babies are grown outside of the body and raised communally in a Godless society. Moreover, at a 1949 House of Lords debate the Archbishop of Canterbury, Geoffrey Fisher called AID adultery. ${ }_{72} \mathrm{~A}$ Methodist Conference in 1958 agreed that the practice was "a breach of the marriage vow." 73 The same year, the Lambeth Bishops argued this "would not be in any way diminished by resolving the legal difficulties which at present surround the practice." 74 At the time, objections to artificial insemination were not moral alone. In the days before IVF, when fertilisation still took place in the womb, there were significant health risks for the mother. This was enough of an issue for the British Medical Association to advise against the use of AID at its 1950 AGM.75

The Church of England formed a committee in 1945 to discuss artificial insemination. Members included Bishop Barnes of Birmingham and the Bishops of Derby, Alfred Rawlinson and Oxford, Kenneth Kirk. The group felt an initial repugnance to the idea, unable to overcome the seemingly 'unnatural' nature of the practice. The three Bishops then interviewed among others, the Minister of Health, several prominent doctors and Carlos Blacker. Rather than condemn the practice outright, the best course of action for AlH "as between husband and wife," was simply that "judgement should be reserved." 76 A eugenicist himself, Barnes was torn on the issue, confessing to the Archbishop of Canterbury that: "If the Church yielded

\footnotetext{
67 Julian Huxley, 'Foreword' in H. Brewer, Eugenics and Politics (London: Eugenics Society, 1937), 1. 68 Herbert Brewer, Eugenics and Politics (London: Eugenics Society, 1937), 3.

69 Richards, 'Artificial Insemination and Eugenics,' 213.

70 Martin Richards, 'Artificial insemination and eugenics: Celibate motherhood, eutelegenesis and germinal choice', Studies in History and Philosophy of Science Part C 392 (2008), 211.

71 Blacker, Statement of Objects, 8.

72 'Lords Debate on Artificial Insemination', The Times (17 March 1949), 4.

73 'Notes of the Quarter' (October 1958), 155.

74 Bailey, 'The Lambeth Conference and the Family', 244.

75 lbid.

76 John Barnes, Ahead of His Age, 429.
} 
to the very strong instinct which moves most of us personally, [...] it might be that in years to come men [would] point to our decision as another example of the way in which, when a new departure was made, the Church sought to block the way of progress." 77 For AID, it was concluded that "grave exception should be taken from the Christian point of view."78

With these issues considered, the British Council of Churches formed an Advisory Group on Sex, Marriage and the Family in 1959. In addition to its ecclesiastical members, the Council sought the advice of secular authorities. Derrick Bailey was a key member of the Advisory Group, as was the Medical Secretary of the Family Planning Association, Eleanor Matthews and A.J. Bradshaw, Secretary of the Marriage Guidance Council. The Group's findings were published in 1963 as Human Reproduction: A study of some emergent problems and questions in the light of the Christian Faith. In her review for the Eugenics Society, Bosanquet said that it "fully deserves to be read and pondered by all thoughtful people, both Christian and agnostic." 79 The report had two aims: first, to inform both clergy and laity about recent and possible future developments in human reproduction; and second, to discuss some basic questions raised by these techniques. On contraception, the authors agreed with the position established at Lambeth in 1958. Indeed, among the foremost of mankind's problems were "the perils to peace and to the whole quality of human life of an uncontrolled birth-rate" and birth control was a moral necessity. However, there was now unparalleled power to control population size and this should be met with caution: "How much is man called upon to be an active and deciding fellow-worker with God? [...] Is this a power which invades the sphere which should be reserved for God's sole action?" ${ }_{80}$ With birth control accepted, where should the line be drawn on interfering with procreation? This question pervades the whole publication. Moreover, while eugenics is not wholly denounced, the connection between selective breeding and disastrous philosophies like German National Socialism is reiterated throughout as a stark warning to all.

Influenced by Bailey, Matthews and Bradshaw, the report displays reluctant sympathy for eugenics. In terms of negative eugenics, it is recommended that Family Planning should guide "those contemplating marriage or parenthood who suffer from diseases obviously capable of being inherited." ${ }_{81}$ However, sterilisation was not acceptable because in the most severe cases of mental deficiency the patient was unable to give consent. 82 The Group were less certain about isolated cases. Indeed, Bailey admitted that AID had been used in families where the father had epilepsy: "which, of course, is a eugenic use of this technique." Notably, the committee made it clear that "Eugenic considerations have their place. National planning of a very indirect kind may rightly take them into account (e.g. by abstaining from tax arrangements which weigh very heavily on those who would benefit the community most by reproducing their kind)." With negative eugenics greatly criticised at the time, many post-war eugenicists focussed almost exclusively on positive eugenics such as this. Indeed, the approach was shared by the Eugenics Society President, Charles Galton Darwin (1887-1962), who proposed financial support to increase the

\footnotetext{
77 Ernest W. Barnes, 'Reply to Fisher RE: Artificial Insemination,' (20 February 1945), EWB 9/21/10. 78 'Committee on Artificial Insemination: Draft Interim Report,' (est. July 1945), EWB 9/21/28.

79 Barbara Bosanquet, 'Review: Human Reproduction', The Eugenics Review 55, 1 (April 1963), 37. 80 The British Council of Churches, Human Reproduction: A study of some of the emergent problems and questions in the light of Christian faith (London: The British Council of Churches, 1962), 29. 81 The British Council of Churches, Human Reproduction, 30.

82 lbid, 26.
} 
size of middle class families in his Promising Families Committee. There is also evidence to suggest that universities paid lecturers to have more children also for eugenic purposes. Founder of the Welfare State, William Beveridge (1879-1963) admitted to the Eugenics Society during the war that LSE had adopted this. As Julian Huxley summarised: "negative eugenics is of minor evolutionary importance and the need for it will gradually be superseded by efficient measures of positive eugenics." 83

Human Reproduction features a lengthy discussion on artificial insemination and the philosophical implications of mankind's increasing power over future generations. The Advisory Group tentatively accepted AlH if used to "bring a child into an infertile marriage." ${ }_{84}$ However, the reader is warned that in the field of human reproduction "the greatest care and judgement" must be exercised "in evaluating the contribution which scientific techniques may bring to a truly human life." This view was universal at the time. Richard Hoggart has documented that most working class families believed that for all of the developments by 'the scientist', from penicillin and atomic energy to contraception and artificial insemination, "working-class people persist in assuming that there is a straight-forward moral responsibility in both the act of engagement in, and the application of, such discoveries." 85 With contraception, mankind could control "the number of persons on this earth," but with artificial insemination "also the kind of persons they shall be." It would not be long before "we shall be confronted with far-reaching eugenic proposals" in which we can "choose the sex of our children. This is a simple choice, but massively charged with potential effect on the future." The comparison is made with the Nazi Lebensborn project, in which 'superior' Nazi officers would father children with multiple Aryan mothers to be raised communally. This was recognised by eugenicists. Blacker considered the idea that while eminent men and women could "be courteously asked by the President of a National Eugenics Corporation to contribute to posterity a portion of their sexual glands", to some "these possibilities will appear fascinating, to others abominable." 86 Thus, it was asked: should such techniques be used to "enable the nation to breed from the best stocks?"

To answer this question, the committee considered the ideal Christian family. God's purpose for procreation was that "persons should enter this world through the closest of all relationships, whereby two persons become 'one flesh' and that, by the semen of the one fertilising the ovum of the other, another person should be conceived possessing genetic characteristics of the two persons thus fused together." It was doubted that a national eugenic programme of selective breeding could ever be reconciled with this modern Christian conception of a free person. Moreover, while intelligence, physical strength and the presence of hereditary disease could be subject to genetic control, the committee was "unaware of any claim by responsible eugenicists to be able to breed spiritual or moral capacities." 87 Eugenics could not be used to bring mankind closer to God. This could only be achieved by preserving the freedom to choose your life partner - this is what drove the evolution of mankind, as per the conclusions of the Advisory Group. After careful consideration, AID was rejected. It both alienated mankind from God and could be abused by totalitarian governments to breed humans like livestock (the technique had only been recently applied to cattle breeding). AID's use "on a large scale for

83 Julian Huxley, 'Eugenics in Evolutionary Practice', The Eugenics Review 54, 3 (October 1962), 135. 84 Human Reproduction, 30.

85 Hoggart, The Uses of Literacy, 45.

86 Blacker, 'Artificial Insemination', 53.

87 Quoted in Ibid. 
purely eugenic purposes would be wholly unjustifiable from the Christian standpoint. This would drastically reduce the intensely personal element which we believe must rightly be involved in the reproduction of persons; and they would do it for purposes which do not represent what the Christian believes to be the will of God in making man." 88

While the Eugenics Society gave its support to AID and the Anglican Church did not, it has never been used in a national eugenic programme. Despite the reservations of the Anglican Church, sixteen years later the first 'test tube' baby, Louise Brown was born in the UK in 1978. The development of IVF brought artificial insemination into the mainstream. After the 1990 Embryology Act, it became available in Britain from a donor or otherwise on the NHS and privately, with waiting lists long and costs high respectively. Meanwhile, the 'sperm bank' became a commercial industry in the United States and more recently has reached mainstream cultural status with humorous portrayals in episodes of well-known series like Friends (1996, 2003) and Parks and Recreation (2013). Notably, the storyline for both shows feature independent women with successful careers wishing to become pregnant and raise children alone. This both goes against the attempts of midtwentieth century British churchmen and eugenicists to preserve traditional family structure and confirms their fear that artificial insemination could divorce procreation from marital union.

\section{Conclusion}

British eugenicists and churchmen successfully campaigned in the 1950s and 1960s for the introduction of new laws on birth control and abortion. The Lambeth Conference of 1958 remains a landmark moment for the Anglican Church solidifying its status as a progressive Christian institution that kept the moral interests of the community at its forefront. The Eugenics Society helped push through legislation on Family Planning to reduce the working-class birth rate. Either way, contraception and abortion are more readily available than ever in Britain. Eugenicists also believed that AID could be used to ensure future generations would have no genetic disease. However, the Anglican Church were generally repulsed by the idea - the sacred act of procreation was between man and wife only. AID has been developing ever since and is used by more people than ever, whether independent women, a same-gender couple, or as eugenicists and churchmen wished, in the 'traditional' family of man and wife.

Contrasting opinions on artificial insemination also continue today. "Be special, give sperm" is the advertising slogan of Britain's largest sperm bank, located in London. However, not everyone is suitable for this elite group of special sperm givers. In 2015, The Guardian published an article on the 'eugenic' nature of the London Sperm Bank, which described "a policy of turning away autistic donors and those diagnosed with other neurological disabilities, such as attention deficit hyperactivity disorder [ADHD], dyslexia and obsessive compulsive disorder." 89 On behalf of the Autistic Self Advocacy Network, Ari Ne'eman argued that "eliminating

\footnotetext{
88 Bosanquet, 'Review: Human Reproduction', 37.

89 Ari Ne'eman, 'Screening sperm donors for autism? As an autistic person, I know that's the road to eugenics', The Guardian (30 December 2015),

[http://www.theguardian.com/commentisfree/2015/dec/30/screening-sperm-donors-autism-autisticeugenics, accessed: 7/11/16].
} 
autism, dyslexia and other similar disabilities might remove valuable talents, [and] such changes may leave humanity less equal, less diverse, and perhaps even less human." This is comparable to the approach of Anglican churchmen in the 1960s, who argued that humanity's variation was part of God's evolutionary plan. Were the Anglicans right in saying that variation is an essential component of humanity's success?

Elsewhere, the term 'designer babies' has been in vogue for some time.90 Early this year, the development of three-person babies (a technique that uses donor mitochondria to prevent inheritable mitochondrial diseases like deafness and epilepsy) too has led leading scientists like Madhumita Murgia to suggest that "Eugenics is a dirty word, most commonly associated with racist profiling, or Nazi experiments. But the time has come to rethink our attitude." While isolated cases may not fulfil the eugenic goal of controlling human evolution, that the terms association with gas chambers and concentration camps is beginning wane is significant.

Finally, the problem of overpopulation highlighted by churchmen and eugenicists alike in mid-century Britain only increases. Last year China brought an end to its 35 year one child policy. Originally designed to combat population growth, it became widely associated with forced abortions, sterilisations and even infanticide. Many have heralded the decision as a "rare human rights victory in a country where freedoms are tightly restricted" agreeing with the Anglican warnings in Human Reproduction on how new techniques of reproduction could be abused in dictatorships. However, Sarah Conly, author of One Child: Do We Have a Right to More (2015), argues against China's decision: "More people will mean more unsustainable resource use, worse climate change, and, eventually, wars over scarce goods or massive population displacement and migrations to places with remaining resources." In response to these global fears, Bill Gates (whose Dad was head of Planned Parenthood) one of the world's richest men, has put a massive proportion of his fortune in spreading the once eugenic philosophy of responsible parenthood to the Third World. Yes, eugenics is a dirty word and yes, some midcentury religious leaders were not progressive. However, now more than ever, the arguments of both are invaluable as we look once again to the future of the human species.

90 My god no, just think if Victoria Beckham ever understood a word of what you said, the horror of the designer baby that she would demand". With 24 'likes' this was the most popular comment on a 2013 Guardian article titled, 'Designer babies": the ultimate privileged elite?' [https://www.theguardian.com/commentisfree/2013/jul/09/ivf-baby-born-genetic-selection-ultimateelite accessed 4 March 2017]. 